\title{
The development of a school- based psychotherapy service for adolescents
}

\author{
T. J. Dyer and F. M. Elliott
}

In this afticle wo give on attemattve viow of service provision for adolescents with emotionat dificulitic: centred around four high schools. We bellove that the senvice wo offer aliters in a number of ways and hos a number of benefits for cllents and other puplis and stafl of the schooks. We present this viow of our service with somo information cbout ths historicel context and as a enepenot of the current state of the service in the expectation that there will bo further developments.

\section{Backeround}

Our service is based on a number of beliefs, the most important of which are the following.

(a) Psychotherapy requires the presence of a psychotherapist and the presence of a patient or client. As we realise this philosophy we are able to own the flexdbllity to work in circumstances which are often deemed inappropriate for the practice of psychotherapy.

(b) The essence of successful psychotherapy is any process which enables patients or clients to manage emotions, commonly anger and/or sadness, with which they are struggling. There are many routes by which this can be achieved.

(c) The only tool the psychotherapist has is his or her self, but this will be sufficient If the therapist has an adequate level of skdil, resourcefulness and experience, and is able to engage the patient.

(d) Predominant among the needs of adolescents is their requirement for clarity of communication, particularly in relation to limit setting. from significant adults in their lives.

(e) The solution is more important than the problem. We gather enough information on the nature of the problem to allow us to move towards a solution. After many years of experience we can usually gather this information quickly. We believe that dwelling on the problem at length enhances its power.

\section{Fistory}

The eastern third of Clwyd has a population of about 135,000 , the majority residing in a number of small towns. The area was hit by the closure or contraction of major employers in the 1980s.

We have had a child guidance service since the 1960s, and it deals with approximately 100 referrals a year. In 1982 TJD joined the service and went on to develop it using Ideas predominantly from family therapy. Three years later FME joined the service, bringing his own experience, interest, and expertise in group and individual psychotherapy with adolescents (Bruggen \& Elliott, 1979; Cowmeadow \& Elliott, 1975).

In order to extend the range of treatment offered, we developed a weekly out-patient psychotherapy group for 18 to 20 adolescents over the next two years (Loftus, 1988).

A marker of the success of this group was that some local high schools noticed dramatic and continuing improvements in the behaviour and emotional stability of pupils who were attending the group. This service had already developed links with many of the high schools in the catchment area making it easy for them to approach us and satisfy their curiosity about the changes they were observing.

At the same time as the out-patient group, experiential training workshops were run by the group leader. These were open to any professional working with adolescents who expressed an interest. Schools could pursue 
their interest in what was happening in the service through the attendance of some of their staff at the workshops. The workshops were popular. Many participants used them to make significant advances in the quality of their work with others and in their awareness of themselves.

In response to the enthusiastic reports of the staff who had attended the workshops, a high school approached the service to request that the senior clinical nurse specialist run a group, for their pupils, on their premises. The service responded to the request and started a group. Referrals were made to the group by the school's special needs co-ordinator.

The school was impressed by rapid and sustained improvements in many of the youngsters referred. The group was successful in engaging a number of pupils who had otherwise very little commitment to the school curriculum. There were times when some pupils only attended school in order to go to the group meetings.

Having found the group very successful, the school asked for additional input from the senior clinical nurse specialist in terms of individual counselling or psychotherapy sessions for pupils whose emotional state was causing the staff concern. This was negotiated and agreed, and referrals were again made by the special needs co-ordinator.

News of these developments spread to other high schools in the catchment area and soon some of them were asking for a similar service. To date, four high schools recetve direct input from the senior clinical nurse specialist.

\section{Current service}

In one of the four high schools there is a psychotherapy group led jointly by the senior clinical nurse specialist and the special needs co-ordinator. In this school and the other three we also offer the following.

(a) Individual psychotherapy for pupils.

(b) Supervision for members of staff who are offering counselling to pupils.

(c) Consultation for teaching staff who are experiencing difficulties in handling certain situations with some of their pupils.

(d) The opportunity for the senior clinical nurse specialist to see one or both parents of some of the pupils he is seeing individually. This occurs either in conjunction with a member of school staff in the school, or in the parents' home.

(e) Input into discussions about school policy related to emotional and behavioural problems presented by pupils.

It is made clear that we give priority to pupils who are experiencing emotional difficulties. The commonest problems for which we offer help are depression, the results of bereavement, and the results of physical, emotional, or sexual abuse. Sometimes these problems present as difficult behaviour. Antisocial behaviour which is not the result of emotional conflict is not seen as a reason for referral to the individual psychotherapy resource.

We believe the following benefits arise from the provision of such a service.

(a). Help is provided to youngsters struggling with adolescence at an early stage in their difficulties.

(b) Pupils do not recetve a psychiatric label.

(c) Pupils have access to psychotherapeutic help without either they or their parents having to negotiate the hurdles which often lie in the way of access to such help. We believe that many pupils receive help who would not otherwise present to a more traditionally organised service. At a recent leaving ceremony for fifth form pupils, it was noted that around $20 \%$ of the year had had at some point in their school career sessions with the senior clinical nurse specialist.

(d) In all four high schools there have been significantly fewer exclusions from school since the inception of the service. The average number of indefinite or permanent exclusions in the schools served over the last six years is 2.26 per 1000 pupils per year, compared with 2.99 in the rest of Clwyd. Currently, the level of exclusions from school is a major cause for concern in high schools and education authorities throughout the country.

(e) The school staff feel more confident in dealing with antisocial behaviour and with emotional problems among their pupils than they did prior to the inception of the service. As a result, benefits accrue to many more pupils than the number who receive direct help from the clinical nurse specialist. 
(f) The service is cost effective. Approximately 130 referrals are seen each year in the schools at a cost to the employing authority of one whole-time senior clinical nurse spectalist.

\section{The future}

We are engaged in the process of recruiting additional staff who will undertake a period of training before joining in providing an expanded service. We are negotlating with a number of schools which have requested our service in the past and are keen to take up the possibility of help in the future, organised along the lines set out above. We feel heartened by the support offered to this innovattve service by our employers, particularly in a time more commonly characterised by contraction rather than expansion of services.

\section{References}

BRUGGEN, P. \& EuOTT, F. (1979) Touch and body language in family therapy. Joumal of Family Therapy. 1, 221229.

Cowmendow, P. \& Eurotr, F. (1975) Sexuality and violence as defences against the pain of death and rejection. Therepeutic Education. 3. 1.

LorTus, M. (1988) Moving to change: action groups in an out patient setting. Journal of Adolescence, 11, 217-229.

T. J. Dyer, Consultant Child and Adolescent Psychiatrist; and F. M. Elliott, Senior Clinical Nurse Specialist, Deeside Child and Adolescent Service, 16 Wepre Drive, Connah's Quay, Deeside, Cluyd CH5 4HA

\title{
A pharmacy-controlled lithium clinic
}

\author{
Mary E. Courtney, Janine A. Acomb and Veronica Lovatt
}

\begin{abstract}
A phamacy-run lithlum cllnic was set up in a district genoral hospltal in order to sove modical stefl time, utillse pharmactst skells and provide on efinclent ltthlum monlioing senvice. Alter one year the clinke wos oveluated in ferms of the control of serum ithlum lovels, the acceptabillty of the arrangements to the patients and the patients' knowlodos of and aftitude fowards lithlum therapy. We sugoest this model of a lithium clinic could be usetully adopted in other poychlatilic doperiments.
\end{abstract}

Patients taking lithium require regular monitoring of their serum lithium levels, and of renal and thyroid function (Schou, 1986). Supervision of lithium treatment may be undertaken by general practitioners, or by specialist hospital services either in general psychiatry out-patient clinics or in specialised lithium clinics. Kehoe \& Mander (1992) in their comparison of lithium monitoring in hospital and in general practice found that patients supervised by their GP had lithium levels checked less frequently and were more likely to experience lithium levels above the therapeutic range.

The therapeutic effectiveness of lithium is obviously dependent on patient compliance, which can be improved by patient education. As lithium is potentially toxic under certain conditions, it is important that patients have accurate and comprehenstve knowledge about its use. Peet \& Harvey (1991) have shown that a patient education programme incorporating videotaped and written material improves patients' knowledge about lithium and their attitude towards lithium therapy. Such an education programme increases the safety of lithium treatment and could well improve compliance.

With the government's Health of the Nation suicide targets and the well-known suicide risk associated with affective disorder, prophylaxds has become an increasingly important area of concern among psychiatrists. The WHO Mental Health Collaborating Centres (1989) in their 